\title{
THE PLACE OF MELOXICAM IN THE SERIES OF MODERN NON-STEROIDAL ANTI-INFLAMMATORY DRUGS
}

\author{
G.V.Zaychenko, O.M.Lyapunov, O.P.Bezugla \\ National University of Pharmacy \\ State Scientific Institution "Institute for Single Crystals" of the NAS of Ukraine \\ Key words: non-steroidal anti-inflammatory drugs; meloxicam; rheumatologic diseases
}

\begin{abstract}
The article describes the pharmacological characteristics of the first selective COX-2 inhibitor meloxicam, aspects of its mechanism of action, peculiarities of pharmacodynamics and indications, as well as the advantages of the drug compared to the classic and highly selective NSAIDs in terms of safety. The efficiency and safety of meloxicam have been confirmed in 230 clinical trials, in which more than 30 thousands patients took part. In most of them it has been proven that meloxicam is as effective as classic NSAIDs, and moreover, it has a high safety profile, particularly with regard to the GI tract. By severity of the anti-inflammatory and analgesic effect meloxicam is not inferior to conventional NSAIDs, and compares favourably with them by good tolerability with regard to the gastrointestinal and cardiovascular safety, and it can be recommended as a drug of the first choice for the treatment of inflammatory and degenerative arthropathies.
\end{abstract}

Non-steroidal anti-inflammatory drugs (NSAIDs) take one of the most important places in clinical practice. The broad spectrum of NSAIDs is stipulated by the unique combination of pharmacological properties, which allow considering them one of the most widely used group of drugs [3]. NSAIDs have been successfully used in the therapy of most rheumatologic diseases. Due to their high clinical efficiency, impact on the main manifestations of the inflammatory process (pain, edema, fever), rapid clinical effect, the absence of reduction of the therapeutic efficiency during prolonged treatment they are used in cases of both inflammatory diseases - rheumatoid arthritis (RA), seronegative spondylarthrosis and in degenerative cases such as osteoarthritis (OA), osteochondrosis, diseases of paraarticular tissues [12, 17].

However, in spite of the obvious clinical efficiency, the use of NSAIDs has its limitations. The problem matter of the modern rheumatology is development of gastropathies against the background of the therapy by the drugs of this NSAID group; these gastropathies have a negative effect for adherence of patients to the therapy, and make them refuse from further therapy [46]. In some cases NSAID gastropathies may have real hazard for the life of patients [61]. For example, in the USA the death rate caused by the NSAID induced lesions of the gastrointestinal tract equals the death rate caused by the AIDS, and it is higher than the death rate caused by melanoma, bronchial asthma, carcinoma of the uterine cervix or lymphogranulomatosis [10]. In individuals, who take NSAIDs constantly, the frequency of erosive and ulcer changes is compared to the frequency of such pathology development in patients of the gastroenterological profile [69]. It is also generally known that different classes of NSAIDs are hepatotoxic, nephrotoxic and cardiotoxic in different degrees [4].

Though the experience of the NSAID application has more than 100 years, the most important aspects of the mechanism of action of using these drugs were found out only in the 70-th of the last century [6]. It has been determined that the most important link of the mechanism of the NSAID action is their ability to inhibit the activity of cycloxygenase (COG) enzyme and thereby to reduce the synthesis of prostaglandins (PG) and other mediators of inflammation. According to the modern conception, COG is a multienzyme complex, including dioxygenase, isomerase, reductase and other components. COG is a hemoprotein located within the endoplasmic reticulum near the sites of arachidonic acid release from membranous phospholipids under the influence of phospholipase enzyme A2. In the presence of molecular oxygen and a number of co-factors COG catalyzes two key reactions in transformations of arachidonic acid leading to cyclic endoperoxides formation. The first of these reactions is oxidation with addition of oxygen in positions 9, 11 and 15 of the arachidonic acid molecule and formation of the intermediate compound - PG G2. The second reaction is conversion of $\mathrm{PG} \mathrm{G} 2$ into $\mathrm{PG} \mathrm{H} 2$, which is the precursor of other PG types (E, F), as well as prostacyclin and thromboxanes A2 and B2. The PG series (especially $E$ series) refers to the number of major mediators and modulators of inflammatory reactions - microcirculation disorders, edema appearance, algesia, hyperthermia. Thromboxane, in favour of which the cascade of arachidonic acid functions in platelets, is the powerful factor of their aggregation. Prostacyclin formed in the vascular wall, on the contrary, weakens platelets aggregation and promotes vasodilatation. The PG effects are enhanced by free radicals of the "hydroxy"-type; they are formed during the enzyme oxidation of arachidonic acid, damage cell membranes, and promote the release of aggressive lysosomal enzymes [12, 13].

COG and the main mechanism of action for NSAIDs was discovered in 1971 by the English pharmacologist $\mathrm{J}$. Vane, and later it was found that there were at least 
two isoforms of this enzyme - constitutional (COG-1) and inducible (COG-2). They are different by their structure, coded by different genes and perform different functions: COG-1 is responsible for the synthesis of thromboxane and $\mathrm{PG}$, which regulate such physiologic functions as mucous membranes protection, platelets aggregation, glomerular filtration, renin secretion, renal blood flow, water-electrolytic balance, etc. [10, 46]. COG-2 is preferably responsible for the synthesis of $\mathrm{PG}$ taking part in development of the inflammatory process, pain and fever. Discovery of COG isoforms allowed the scientists to suggest that therapeutic effects of NSAIDs are associated with COG-2 inactivation; adverse effects, in particular gastrotoxicity, are connected with COG-1 inhibition. The mechanism of the gastric mucous membrane lesions induced by taking NSAIDs is associated with COG-1 inactivation, inhibition of the PG synthesis inside the gastric mucosa, decrease of indirect PG production of the protective mucus and bicarbonates; it leads to appearance of erosions and ulcers, which can be complicated by bleeding and perforation $[4,12,13,46]$. Thus, the efficiency and safety profile is determined by the NSAID ability to suppress COG activity to different extents [2].

The data obtained have determined the direction of the new generation of NSAIDs, which possess selectivity in relation to COG-2. The modern classification distinguishes NSAIDs by their ability to affect COG-1 and COG-2 and includes the following groups of drugs: - $\quad$ selective COG-1 inhibitors (low doses of acetylsalicylic acid);

- nonselective COG inhibitors (the majority of traditional NSAIDs: indometacin, ibuprofen, dexibuprofen, flurbiprofen, naproxen, diclofenac, aceclofenac, ketorolac, tenoxicam, pyroxicam, lornoxicam, etc.; - prefarably selective COG-2 inhibitors (meloxicam, nimesulide, nabumeton, etodolac);

- $\quad$ specific (highly selective) COG-s inhibitors (coxibs);

- $\quad$ selective COG-3 inhibitors (paracetamol, sodium metamizol) [2].

In 1985 the first partially selective drug called nimesulide ("Aulin") appeared at the pharmaceutical market. At the end of the 80-th the specialists in "Beringer Ingelhaim" got the formula of meloxicam with the higher selective activity. In 1993 the veterinarian subdivision of the company ("Bereingher Vetmedica") produced meloxicam intended for use in dogs. The drug was registered under the trade mark of "Metacam" in Great Britain and Germany. In 1995 the dosage form of meloxicam for human was developed. The drug was registered under the trade name of "Movalis" in several European countries. By the end of the year of 2000 the drug was approved in more than 40 countries, including USA, Japan and Canada. Thus, meloxicam is the first selective COG-2 inhibitor $[6,33]$.

According to the IUPAC nomenclature the chemical name of meloxicam is 4-hydroxy-2-methyl-N-(5-methyl2-thiazolin)-2H-1,2-benzothiazian-3-carboxamide-1,1dioxide. The structural formula is $\mathrm{C}_{14} \mathrm{H}_{13} \mathrm{~N}_{3} \mathrm{O}_{4} \mathrm{~S}_{2}$. By the chemical structure the compound refers to the oxicam group (or enolic acids), which representatives are characterized with a potent analgesic and anti-inflammatory action in combination with favourable pharmacokinetic characteristics, first of all, with a long half-life [5].

It is interesting to note that unlike the NSAID series, which are carboxylic acids derivatives, meloxicam as the majority of selective COG-2 inhibitors contains sulfonamide group in the composition of its molecule [2].

The main mechanism of action for meloxicam along with other NSAIDs is stipulated by its ability to suppress the COG-2 activity. The blockage of this enzyme activity leads to inhibition of the inflammatory response, the marked relief of the pain syndrome and decrease of temperature in the focus of inflammation. Meloxicam has $5-20$ fold selectivity in relation to $\mathrm{COG}-2$ compared to COG-1 [25].

The ratio of the activity of NSAIDs as for its COG-1/ COG-2 inhibition allows suggesting about their potential side effects. The less is this value, the more selective the drug in relation to COG-2 is, and, thereby, it is less hazardous. This value for meloxicam is 0.330 .33 [2]. In a number of experimental studies it has been proven that when meloxicam is used in therapeutic doses, it has little impact on the COG-1 activity, and thus has a rather high level of safety [5, 69].

Besides, its inhibiting effect on the PG synthesis the mechanism of action of meloxicam is also associated with its effect on other links of the pathogenesis of inflammation, pain and fever. Meloxicam increases the content of the intracellular $\mathrm{Ca}^{2+}$ in T-lymphocytes, it promotes the interferone- 2 synthesis; prevents release of lysosomal enzyme outside the cell, reduces capillary permeability due to stabilization of hyaluronic and chondroitin-sulphuric acid [11]. The drug inhibits oxidative phosphorylation (disturbing the synthesis of glucosaminoglycans resulting in inhibition of proliferation processes) and development of the fibrinoid phase of inflammation in RA. The effects of PG are increased by free radicals, which are formed by enzymic oxidation of arachidonic acid and damage cellular membranes. Therefore, like for the other drugs of this group, the ability to inhibit phagocythosis and neutralize active forms of oxygen and products of lipid peroxidation formed in the process of inflammation, as well as decrease formation of the platelet activation factor, the necrosis factor of tumour- $\alpha$, proteinases and other mediators of inflammation is important for the mechanism of action of meloxicam. Meloxicam also decreases production of macroergic compounds; it reduces the energy supply of the focus of inflammation $[5,11]$.

As previously stated, meloxicam has favourable pharmacokinetic characteristics. The drug is easily and rapidly absorbed through the gastrointestinal tract mucosa. The maximal concentration in plasma is observed in 5-6 hours after the intake. A stable concentration is reached on the 3-5-th day of therapy, and it prolongs the time of a stable clinical effect [20]. When introduced intramuscularly the drug is rapidly absorbed into the bloodstream. The maximal concentration in plasma is reached in 1.5 hours. The indicator remains stable within 5-6 hours after use. 
Up $90 \%$ of the drug is in the bound state with proteins. Meloxicam is biotransformed in the liver with formation of 4 inactive metabolites eliminated from the organism together with urine and feces $[45,56]$. In patients with the moderate liver and kidney insufficiency the pharmacokinetics of meloxicam practically does not change. The drug bioavailability is $90 \%$. The important feature of the drug is the absence of a significant effect of food and antacid drugs on its bioavailability. The elimination halflife is 20 hours; it allows taking the drug once a day. It is convenient for use and promotes strict treatment compliance; it is especially important in cases of prolonged therapy of severe rheumatologic diseases. Another advantageous and distinguishing feature of meloxicam is its compatibility with antacids, acetylsalicylic acid, methotrexate, warfarin, furosemide - the drugs most commonly taken by the patients of the middle and old age suffering not only from rheumatologic diseases, but also from cardiovascular system diseases, disorders of water-salt metabolism, hypercoagulation syndrome [5, 29, 32].

For today the original drug of meloxicam - "Movalis $®$ " (Beringher Ingelhime, Germany) is represented at the Ukrainian pharmaceutical market only in two dosage forms (solution for injection and tablets). Generic versions of meloxicam are produced in the form of enteric and topical medicinal forms: in the form of $1.5 \%$ suspension for internal use, tablets in the doses of $7.5 \mathrm{mg}$ and $15 \mathrm{mg}$, rectal suppositories with the active substance content of $7.5 \mathrm{mg}$ and $15 \mathrm{mg}$ together with $1.5 \%$ solution for intramuscular injection, as well as in the dosage form for external application - in the form of $1 \%$ gel. The availability of parenteral medicinal form is the advantage of meloxicam not only in comparison with the standard NSAIDs, but also with other selective drugs, and it gives possibility to use its analgesic potential in greater extent.

In intramuscular introduction the local reactions in the form of focal necrosis, creatine kinase increase do not develop; it distinguishes meloxicam from the series of other NSAIDs [20]. The parenteral medicinal form of meloxicam has been successfully used in cases of acute inflammatory osteopathy, as well as in the pain syndrome intensification in patients with OA, pain in the back and neck, periartricular and postoperative pain syndromes. Combination of injection and peroral dosage forms allows to perform the multistage therapy having a wide application in clinical practice; it allows to arrest the pain quickly and effectively by means of injections and then continue therapy for the time required and in the enteric medicinal form that is suitable for a patient [26].

The indications for meloxicam are RA; OA; ankylosing spondylitis (Bechterew disease) and other inflammatory and degenerative diseases of joints, spinal column accompanied with the pain syndrome, as well as primary dysmenorrhea $[4,5,17]$.

In spite of its relatively short period of existence at the pharmaceutical market meloxicam has very reliable evidential base, it means that its efficiency was confirmed by the results of 230 clinical trials, in which 30 thousand patients took part [31]. In the majority of cases it has been proven that by its efficiency meloxicam is not less effective than classical NSAIDs, and along with it, this drug has a high safety profile, first of all, in the gastrointestinal tract.

One of the first clinical trials carried out for assessment of the meloxicam efficiency and safety was the large-scale international prospective double-blind randomized study MELISSA (Meloxicam Large-scale International Study Safety Assessment) (1998, Hawkey C., Steinbruck K.) $[13,42]$. More than 9 thousand patients with OA received meloxicam in the dose of $7.5 \mathrm{mg}$ or sustained release diclofenac in the dose of $100 \mathrm{mg}$ took part in the experiment. The treatment lasted for 28 days. Both drugs showed equal efficiency, however, "Movalis" caused adverse reactions 1.5 times less frequently in the gastrointestinal tract [44]. One more large studySELECT (Safety and Efficacy Large-scale Evaluation of COX-inhibiting Therapies) compared the gastrointestinal safety of meloxicam and pyroxecam [48]. The combined analysis of the results of some studies with participation of more than 5600 patients has confirmed that meloxicam is characterized by significantly less marked gastrointestinal toxicity compared to naproxen, diclofenac and piroxicam $[16,48]$.

Two previous studies considered the evaluation of efficiency and safety of meloxicam in the relatively short period of its administration (for 4 weeks). D. Yocum et al. (2000) carried out the multicentre placebo-controlled randomized study with double masking and parallel groups where the efficiency and safety of the prolonged (12 weeks) use of meloxicam (tablets of $3.75 ; 7.5$ or $15 \mathrm{mg}$ once a day) and diclofenac (tablets of $50 \mathrm{mg}$ twice a day) were compared $[50,62,64]$. The reseach results have shown that with almost comparable analgesic and anti-inflammatory efficiency meloxicam causes unfavourable effects on the GIT significantly less frequently compared to diclofenac and piroxicam $[15,42]$.

More recent investigations have confirmed the assurance that meloxicam is safer as for its effect on the GIT compared to traditional NSAIDs. The meta-analysis carried out by Schoenfeld included the results of the meloxicam use by more than 20000 patients. The main result of the study was in confirming lower frequency of development of NSAID gastropathies in patients taking meloxicam, while comparing with common NSAIDs the frequency of NSAID gastropathies was lower by 48\% [65].

One of the publications (2001, Gagnier P., Reed J.I., Singh G.) compared the efficiency of meloxicam with a number of other NSAIDs (diclofenac, ibuprofen, rofecoxib, piroxicam). In the experiment 1309 patients with OA took part. The first group received meloxicam in the dose of $7.5 \mathrm{mg} / \mathrm{day}$, and the second group took any other NSAID in the mean therapeutic dose. The results showed that meloxicam use was effective in $67 \%$ of patients, while the therapy by other drugs appeared to be successful only in 54\% of volunteers [28].

According to the results of the meta-analysis (polled analysis) based on 28 clinical trials (about 27000 patients) of meloxicam carried out by Singh G. and co-authors the drug in the daily dose of 7.5 is reliably safer 
by $50 \%$, from the point of view of the gastrointestinal complications development compared to diclofenac, naproxen and piroxicam [53, 68, 72]. The same meta-analysis showed the absence of data indicating to the frequency of cardiovascular disorders increasing against the background of meloxicam intake compared to naproxen and piroxicam and less number of thromboembolic complications compared to diclofenac [68].

The analysis of the results of numerous experimental and clinical studies has allowed concluding that meloxicam is not inferior to selective NSAIDs by its efficiency, but at the same time it is characterized by better tolerance and safety $[39,40,63]$. The frequency of side effects as a whole and the gastrointestinal ones in particular, as well as the frequency of the patients' dropout as a result of their development, were significantly lower in the meloxicam group compared to traditional NSAIDs. The risk of development of NSAID gastropathies (gastrointestinal ulcers, perforations and/or bleedings) was almost twice lower when taking meloxicam than when treating with nonselective NSAIDs [67].

The placebo-controlled study by M.V. Domingo et al. (2006) showed that meloxicam could be an optimal choice for patients with hypersensitivity to NSAIDs and acetylsalicylic acid. In addition, the gastrointestinal safety of meloxicam was repeatedly confirmed in terms of the real clinical practice $[19,60]$.

Since OA is one of the main indications for using NSAIDs, it is necessary to know that most NSAIDs have a negative effect on the cartilage tissue due to stimulation of the synthesis of pro-inflammatory cytoxins or inhibition of the proteoglycan synthesis by chondrocytes. According to the data presented by Rainsford K.D. and co-authors meloxicam in the therapeutic concentration does not increase the synthesis of pro-inflammatory interleucin (IL)-1 in the chondrocyte culture and does not have the inhibiting effect on the proteoglycan formation $[18,59]$. According to the experimental data of the study carried out by L. Blot et al. (2000) meloxicam unlike diclofenac possesses the moderate hondroprotective effect, in particular it increases the synthesis of proteoglycan and hyaluronic acid, and also decreases their loss [33]. The results obtained in the short-termed study in vitro with the use of the human cartilage tissue have shown that meloxicam increases the synthesis of proteoglycan and hyaluronic acid in patients with the moderate and severe form of OA. Among all NSAIDs only meloxicam and aceclofenac significantly reduced the pure loss of labeled proteoglycan molecules, and their concentration in the synovial fluid had a positive effect on the general metabolism of proteoglycan and hyaluronic acid in OA $[35,51]$. The hondroprotective action of meloxicam was proven in the study, which lasted a year and a half and carried out by Tsvetkova E.S. and co-authors; in the experiment patients with OA of the knee joint took part. Thus, meloxicam potentially inhibited the $\mathrm{PGE}_{2}$ synthesis in the human chondrocyte culture, preventing chondrolysis, and did not affect the cartilage formation processes and the DNA synthesis in the chondrocyte culture. The data demonstrating the role of chondrocyte apoptosis in the pathogenesis of OA are also a basis for reasonability of using meloxicam in OA [49, 52]. It means that there are reasonable confirmations of the fact that meloxicam is not only chondroneutral, but also possesses a certain hondroprotective potential.

It should be mentioned that the meloxicam molecule is of great interest as a base for analgesics. The injectable dosage form of the drug $(15 \mathrm{mg} / 1.5 \mathrm{ml})$ can be used for relief of acute pain and exacerbation of chronic pain $[34,57]$. The high efficiency of meloxicam administration compared to diclofenac in treating acute lumbago was confirmed by K.Colberg and co-authors $[22,71]$. Significantly more rapid development of the analgesic effect of meloxicam compared to diclofenac was observed. The result of a rapid relief of the pain syndrome was significant improvement of the life quality of patients [19]. In another study there was a rapid analgesic effect of meloxicam in acute lumbago and ischialgia, especially in case of parenteral application in the dose of $15 \mathrm{mg}$ within the first 2 days and for the next 7-10 days $[26,70]$. The analgesic effect of meloxicam increases in combination with muscle relaxants, it is especially important in cases of vertebrogenic pain syndromes [47].

The evidential base as for the meloxicam use in treating the pain in joints was summarized in the systemic review by Y.F.Chen et al. (2008); it included 16 investigations where 22886 patients with OA (12) or PA (4) took part. Their analysis has confirmed that the analgesic and anti-inflammatory activity of meloxicam is comparable with nonselective NSAIDs. At the same time the drug has an obvious advantage over its precursors by lower frequency of complications as for its effect on the gastrointestinal tract. Therefore, when patients take diclofenac, naproxen or pyroxecam, development of NSAID gastropathies is characteristic in average for $17-19 \%$ of patients, but in the therapy with meloxicam the abovementioned fact is characteristic for not more than in $11 \%$ of patients [16, 67].

Meloxicam has gained a reputation of the effective and safe drug for relief of the pain syndrome in OA of faceted joints of the vertebral column - spondylarthrosis $[1,12]$. Spondylarthrosis is characterized by chronic pains and stiffness of the vertebral column, the painful extension is especially limited. Active and passive movements are significantly restricted because of pain and protective muscular spasm. The peculiarity of the vertebral column pain syndromes is the combination of reflex muscular tonic and myofascial syndromes with changes in the emotional sphere, resulting in the pain chronization. Algogenic compounds, such as serotonin, histamine, PG, bradykinin, play a crucial part in the pain impulse formation stipulated by inflammation, damage or ischemia. Prolonged release of inflammation mediators leads to sensitisation of peripheral sensory neurons of the nociceptive conduction system resulting in a chronic pathological process $[23,66]$. PG increases the sensitivity of nociceptors to different stimuli, and correlates their accumulation with intensity of inflammation and hyperalgesia. Since the value of COG-2 at the stage of transformation of arachidonic acid into PG was shown, 
the interest to its role in the pain syndrome development and the mechanism of the pain reduction by COG-2 suppression has greatly increased. Special studies have shown that the COG-2 activity plays a great role in development of hyperalgia, therefore, COG-2 inhibition is considered as one of the most important mechanisms of the anti-inflammatory and analgesic activity [7, 9, 23, 47].

Taking into consideration the pathogenic mechanisms of the pain development and the absolute role of COG-2 in its formation and transmission into the CNS, the use of meloxicam in rheumatology seems a real prospect providing minimization of the complications development while maintaining a high intensity of anti-inflammatory and analgesic effects. The relief of the pain syndrome improves the physical, psychological and social status of the patient, and significantly increases the life quality $[7,8,57]$.

These data substantiate the use of meloxicam as a selective COG-2 inhibitor in the complex therapy of vertebrogenic pain. This type of pain often occurs in old age patients as they are more sensitive to unfavourable effects of medicines. Therefore, it is important that the drug used for treating this pain syndrome must be well tolerated during long-term use, which is necessary in chronic diseases, and well combined with other drugs [9]. Meloxicam meets these requirements. It was confirmed by Valat J.P. et al. in the comparative study of efficiency and tolerance of meloxicam and diclofenac in patients with spondylarthrosis [55]. More than 200 patients took part in the study. These patients were given meloxicam in the dose of $7.5 \mathrm{mg}$ per day dose or diclofenac in the dose of $100 \mathrm{mg}$ per day. The result was assessed before starting the treatment, as well as on the 3-th, 7-th and 14-th days of treatment. Both these drugs demonstrated the similar efficiency: pain in the back significantly reduced in 3 days after the use of both drugs and remained at the reached level by the 14-th day. There were no statistically significant differences in the efficiency of both drugs, while the tolerance of meloxicame was significantly better in compared to diclofenac according to the estimation of both patients and researchers [37].

Meloxicam is widely used in cases of the pain syndrome in the lower part of the back (PSLB). The possibility of its use in the given clinical situation was studied in some foreign investigations [58]. The efficiency and safety of "Movalis" for treating patients with the pain syndrome in the lower part of the back was assessed in the multicentre study carried out in 50 clinics in 15 regions of the RF (V.V.Alekseyev and co-authors., 2008) [1]. Even after the first injection of meloxicam the significant reduction of the pain intensity (spontaneous and during movement) and improvement of the function of the lumbar division of the spinal column was observed. A positive tendency remained when the drug was taken orally, after the completion of 2-4 week course the repeated examination of patients in the majority of cases showed the significant clinical improvement. The increase of the sensitivity pain threshold in patients correlated with the drug therapeutic effect. It indicated the effect of meloxicam on the noci- and anti-nociceptive systems. In 2 years there was significant and comparable reduction in frequency, duration of pain exacerbations and intensity in patients with both radiculopathy and lumbar ischialgia compared to the initial data (before the treatment with meloxicam). Such results gave the authors the ground to affirm that efficiency of the therapy performed was not specific for some distinct component of dorsalgia and had an effect on both the initial and secondary hyperalgia, thus breaking the vicious circle of peripheral sensitisation. At the same time the efficiency of the course treatment is prolonged during the next years; according to the author's point of view, it indicates the possible effect of meloxicam on the central mechanisms of the pain syndrome, and therefore, it determines stability of the positive therapeutic result [1]. The prospective research concerning the study of the meloxicam role in the complex PSLB therapy was carried out by C.Gonzalez Maza et al. (2010) [54].

It should seem that highly selective COG-2 inhibitors must be safer than nonselective ones. However, it turned out that the risk of cardiovascular complications (thrombosis, myocardial infarction and stroke) was significantly higher in cases of coxibs use compared to the treatment with meloxicam (D.Layton et al., 2003). It can be explained by the fact that coxibs while suppressing the COG-2 activity inhibit the synthesis of prostacyclin, but do not affect the synthesis of thromboxane A2, which formation is regulated by $\mathrm{COG}-1$. As a result, the ratio of anti- and prothrombogenic factors significantly shifts to the side of the former $[2,23,45]$. It is clear that with increase of the COG-2 selectivity index there is a high anti-inflammatory and analgesic activity, but cardiovascular complications increase very quickly. Thus, in order to make NSAIDs effective and safe as much as possible, it is necessary to reach the balanced effect on COG-1 and COG-2 [2].

In the study carried out by the method of prescribtion-event monitoring (PEM) it was shown that meloxicam intake in therapeutic doses did not increase the risk of cardiovascular disorders compared to classical NSAIDs $[27,41]$. Besides, the data concerning the cardioprotective action of the drug in patients with the acute coronary syndrome were obtained. It indicates the principle difference of meloxicam from other COG-2 inhibitors, which prescription leads to increase of frequency of myocardial infarction and thrombotic complications according to some data [28, 38].

It is known that the majority of NSAIDs can provoke a bronchospasm and worsen the course of bronchial asthma and pollinosis $[12,21]$. These side effects are stipulated by COG-2 inhibition; therefore, it is possible to suggest that selective COG-2 inhibitors are the most reasonable for the treatment of patients of this category. In connection with it, Bavbek $\mathrm{S}$. et al. tried to answer the question if it was possible to prescribe meloxicam for patients who were prone to "aspirin" bronchial asthma [21]. It was found that the bronchospasm developed only in one patient out of 21 people who took part in the experiment and, therefore, received meloxicam treatment in the dose of $7.5 \mathrm{mg}$ per day. It was demonstra- 
ted in the experiment that meloxicam in the dose of $7.5 \mathrm{mg}$ per day could be the safe alternative to the standard NSAIDs in patients with bronchial asthma and pollinosis [21].

Thus, it should not be forgotten that the main aim of therapy for rheumatologic diseases is to obtain the maximal pharmacological effect by minimization of frequency and degree of severity of the side effects. It means that it is the safety of treatment that gains in significant importance since preferably the chronic clinical course makes the patients take NSAIDs continuously through their whole life. Under present-day conditions of the enormous choice of drugs the data concerning the relative NSAID safety are of greater interest rather than efficiency of treatment $[28,36]$.

Meloxicam is the first preferably selective NSAID having a wide practical application. The drug meets the requirements for NSAIDs, possesses high efficiency with the sufficient level of safety. The efficiency and safety of meloxicam have been proven in accordance with all modern requirements of the evidence based medicine by 230 well planned clinical trials where more than 30000 patients took place [28]. For example, etodolac and nimesulide are significantly inferior to meloxicam by the level of evidence $[3,30]$. The efficiency and safety of meloxicam have been confirmed by the results of its application in clinical practice, including cases of prolonged therapy, as well as in patients with the side effects risk factors (old age, ulcerative disease of the stomach and/or duodenum in anamnesis, simultaneous use of cardioprotective doses of acetylsalicylic acid, etc). At present meloxicam is considered to be one of the most successful NSAID. Meloxicam is registered practically in all developed countries. Among COG-2 selective inhibitors only meloxicam has been registered for treating OA, RA and Bechterew disease, and now it is used by more than 100 million patients [5]. Meloxicam differs from other NSAIDs by the availability of a number of dosage forms (solution for injection, tablets), and it allows to implement the individual approach to anti-inflammatory therapy.

\section{CONCLUSIONS}

It is a fair assumption to say that meloxicam has the optimal "benefit/risk" ratio; by the intensity of its anti-inflammatory and analgesic effect it is as good as traditional NSAIDs and significantly differs from them by good tolerance taking into account the gastrointestinal and cardiovascular safety. Therefore, it can be recommended as the first choice drug for the treatment of pain in the lower part of the back, inflammatory and degenerative arthropathies, rheumatic diseases, and osteoarthritis.

As it is known, the place of the "golden standard" in the series of NSAIDs taken by diclofenac sodium for some period of time is vacant today, and meloxicam has all the chances to become the new standard for the treatment of rheumatologic diseases.

\section{REFERENCES}

1. Алексеев В.В., Алексеев А.B. // Consilium Medicum. - 2007. - №2. - C. 28-32.

2. Безуглая Е.П., Ляпунов А.Н., Либина В.В. и др. // Клінічна фармація. - 2015. - Т. 19, №3. - С. $48-55$.

3. Дроговоз С.М., Штрыголь С.Ю., Щекина Е.Г. Фармакология в помошьь студенту, провизору и врачу: Учебник-справочник. - Х.: Титул, 2013. - 900 с.

4. Каратеев А.Е. // Ревматол. Травматол. Ортопедия. - 2011. - №1. - С. 28-36.

5. Каратеев А.Е., Успенский Ю.П., Пахомова И.Ю. и др. // Науч.-практ. ревматол. - 2012. - №52 (3). C. 101-116.

6. Клиническая фармакология и фармакотерапия / Под ред. В.Г.Кукеса, А.К.Стародубиева. - М.: ГЭОТАРМедиа, 2012. - 832 c.

7. Компендиум 2014 - лекарственные препараты / Под ред. В.Н.Коваленко. - К.: МОРИОН, $2014 .-2448$ с.

8. Кукушкин М.Л., Табеева Г.Р., Подчуфарова Е.В. Болевой синдром: патогенез, клиника, лечение. Клинические рекомендации. - М.: ИМА-пресс, 2011. - 79 с.

9. Курята А.В., Лысунеи Т.К., Зайченко А.В., Черкасова А.В. Боль и проблема безопасности НПВС: Монография. - Днепропетровск: Герда, 2014. - 84 c.

10. Максимов М.Л. // Рус. мед. жсурн. - 2013. - T. 21, №34. - С. 1734-1736.

11. Осипова Н.А., Абузарова Г.Р., Петрова В.В. Принизипы применения анальгетических средств при острой и хронической боли. Клинические рекомендации. - М.: ФГБУ «МНИОИ им. П.А.Гериена Минздравсоиразвития России», 2010. - 67 c.

12. Пасечников В.Д. // Consilium Medicum. - 2013. - №15 (9). - C. 76-80.

13. Штрыголь С.Ю. // Провизор. - 2005. - №2. - С. 10-12.

14. Ahmed M., Khanna D., Furst D.E. // Expert Opin. Drug Metab. Toxicol. - 2005. - №1 (4). - P. 739-751.

15. Altman R., Hochberg M., Gibofsky A. et al. // Osteoarthritis and Cartilage. - 2015. - Vol. 23, Suppl. 2. P. A324-A325.

16. Altman R., Luciardi H.L., Muntaner J. et al. // Circulation. - 2002. - Vol. 106. - P. 191-195.

17. Annigeri R.G., Jadhav M., Juturu T. // Ind. J. of Pain. - 2015. - Vol. 29, Issue 2. - P. 82-85. 
18. Bavbek S., Dursun A.B., Dursun E. // Int. Arch. Allergy Immunol. - 2006. - №142 (1). - P. 64-69.

19. Bosch H.C., Sigmund R., Hettich M. // Curr. Med. Res. Opin. - 1997. - №14. - P. 29-38.

20. Cai W.X., Ma L., Zheng L.W. et al. // Clin. Oral Implants Res. - 2015. - Issue 4. - P. 478-483.

21. Camu F., Shi L., Vanlesberghe C. // Drug. - 2003. - Vol. 63, Suppl. 1. - P. 1-7.

22. Charlton A.N., Benito J., Simpson W. et al. // J. of Feline Med. and Surgery. - 2013. - №15 (8). - P. 678-690.

23. Chen Y.F., Jobanputra P., Barton P. et al. // Health Technol. Assessment. - 2008. - Vol. 12 (Suppl. 11). P. $1-278$.

24. Chou R., McDonagh M.S., Nakamoto E. et al. // Rockville (MD): Agency for Healthcare Research and Quality (US). - 2011. - Vol. 38. - P. 1-148.

25. Coetzee J.F., Mosher R.A., Griffith G.R. et al. // J. of Veterinary Pharmacol. and Therapeutics. - 2015. - Vol. 38, Issue 6. - P. 556-562.

26. Colberg K., Hettich M., Sigmund R. et al. // Curr. Med. Res. Opin. - 1996. - №13 (7). - P. 363-377.

27. Combe B., Velicitat P., Garzon N. et al. // Inflamm. Res. - 2001. - Vol. 50 (Suppl. 1). - P. S10-16.

28. Davies N.M., Skjodt N.M. // Clin. Pharmacokinet. - 1999. - Vol. 36. - P. 115-126.

29. De Menezes S.A.F., Cury P.R. // Intern. J. of Oral and Maxillofacial Surgery. - 2010. - №39. - P. 580-584.

30. Degner F., Leonard J., Sigmund R. et al. // Conference on Progress in the Field of Selective COX-2 Inhibitors; Nice 2001 Sep. 30-Oct. 2.

31. Degner F., Sigmund R., Zeidler H. // Clin. Ther. - 2000. - Vol. 22. - P. 400-410.

32. Del Tacca M., Colucci R., Fornai M. et al. // Clin. Drug Invest. - 2002. - №22 (12). - P. 799-818.

33. Dequeker J., Hawkey C., Kahan A. et al. // Br. J. Rheumatol. - 1998. - Vol. 37. - P. 946-951.

34. Distel M., Mueller C., Bluhmki E. et al. // Br. J. Rheumatol. - 1996. - №35 (Suppl. 1). - P. 68-77.

35. Dreiser R.L., Le Parc J.M., Velicitat P. et al. // Inflamm. Res. - 2001. - Vol. 50 (Suppl. 1). - P. S17-23.

36. El-Rwegi W.M., Elgerwi A.A., El-Mahmoudy A.M. et al. // Int. J. Basic Clin. Pharmacol. - 2015. - №4 (5). P. 924-930.

37. Ghodsi S.M., Mohebbi N., Naderi S. et al. // Iran. J. Pharm. Res. - 2015. - №14 (1). - P. 125-130.

38. Goei The H.S., Lund B., Distel L.M. et al. // Osteoarthr. Cartil. - 1997. - №5. - P. 283-288.

39. Gomes F.I.F., Aragão M.G.B., Pinto V. de P.T. et al. // J. of Oral Implantol. - 2015. - №41. - P. 219-230.

40. Gonzalez Maza C., Moscoso López L., Ramírez Elizalde G. et al. // Acta Ortop. Mex. - 2010. - Vol. 24 (2). P. 88-94.

41. Hassan A.F., Helmy S.A., Donia A. // J. Braz. Chem. Soc. - 2015. - Vol. 26, №7. - P. 126-138.

42. Hawkey C., Kahan A., Steinbrück K. et al. // Br. J. Rheumatol. - 1998. - Vol. 37. - P. 937-945.

43. Hawkey C., Kahan A., Steinbrück K. et al. // Rheumatol. (Oxford). - 1999. - №38 (8). - P. 793-845.

44. Hawkey C.J. // J. Cardiovasc. Pharmacol. - 2006. - Vol. 47 (Suppl. 1). - P. 72-75.

45. Huskisson E.C., Ghozlan R., Kurthen R. et al. // Br. J. Rheumatol. - 1996. - Vol. 35 (Suppl. 1). - P. 29-34.

46. IASP Committee on Taxonomy, 2012 (Международная ассоииачия по изучению боли IASP) http://www. iasp-pain.org.

47. Lapicque F., Vergne P., Jouzeau J.-I. et al. // Clin. Pharmacokinet. - 2000. - №39. - P. 369-382.

48. Layton D., Hughes K., Harris S. et al. // Rheumatol. - 2003. - №42. - P. 1-11.

49. Lee H.J., Kim Y.H., Kim S.H. et al. // Clin. Therapeutics. - 2015. - Vol. 37, Issue 8. - P. e60-e61.

50. Lemmel E.M., Bolten W., Burgos-Vargas R. et al. // J. Rheumatol. - 1997. - Vol. 24. - P. 282-290.

51. Lipscomb G.R., Wallis N., Armstrong G. et al. // Br. J. Clin. Pharmacol. - 1998. - Vol. 46. - P. 133-137.

52. Lund B., Distel M., Bluhmki E. // Scand. J. Rheumatol. - 1998. - Vol. 27. - P. 32-37.

53. Maiden L., Thjodleifsson B., Seigal A. et al. // Clin. Gastroenterol. Hepatol. - 2007. - Vol. 5. - P. 1040-1045.

54. Martin R.M., Biswas P., Mann R.D. // Br. J. Clin. Pharmacol. - 2000. - Vol. 50. - P. 35-42.

55. Matsumoto T., Kudo T., Esaki M. et al. // Scand. J. Gastroenterol. - 2008. - Vol. 43. - P. 490-496.

56. Pablos A.B., Ramalho S.A., König Jr.B. et al. // J. of Periodontol. - 2008. - Vol. 79, №2. - P. 300-306.

57. Povoroznyuk V.V., Bystrytska M.A., Orlyk T.V. // Abstract Book (APLAR, Japan, September 23-27, 2008). 2008. - P. 89.

58. Reginster J.Y., Distel M., Bluhmki E. // Br. J. Rheumatol. - 1996. - Vol. 35 (Suppl. 1). - P. 17-21.

59. Rømsing J., Mysager S., Vilmann P. et al. // Can. J. Anaesth. - 2001. - Vol. 48. - P. 978-984. 
60. Santos A.R.S., Vedana E.M.A., De Freitas G.A.G. / Inflamm. Res. - 1998. - Vol. 47. - P. 302-307.

61. Schoenfeld P. // Am. J. Med. - 1999. - №107. - P. 48-54.

62. Schoenfeld P. // Am. J. Med. - 2003. - Vol. 43 (Suppl 6A). - P. 22-30S.

63. Singh G., Triadafilopoulos G. // Eur. Congr. of Rheumatol. - Prague, 2001, Jun. 13-16.

64. Speranza C., Schmid V., Giraudel J.M. et al. // BMC Veterinary Res. - 2015. - №11. - P. 79.

65. Tavares I.A. // Aliment Pharmacol. Ther. - 2000. - №14. - P. 795-799.

66. Thompson J.P., Sharpe P., Kiani S. et al. // Br. J. Anaesth. - 2000. - Vol. 84. - P. 151-154.

67. Tsubouchi Y., Sano H., Yamada R. et al. // Eur. J. Pharmacol. - 2000. - Vol. 395. - P. 255-163.

68. Valat J.P., Accardo S., Reginster J.Y. // Inflamm. Res. - 2001. - №50 (Suppl. 1). - P. S30-34.

69. Van Hecken A., Schwartz J.I., Depré M. et al. // J. Clin. Pharmacol. - 2000. - Vol. 40. - P. 1109-1120.

70. Wojtulewski J.A., Schattenkirchner M., Barcelo P. // Br. J. Rheumatol. - 1996. - №35 (Suppl. 1). - P. 22-28.

71. Yocum D., Fleischmann R., Dalgin P. et al. // Arch. Intern. Med. - 2000. - №160 (19). - P. 2947-2954.

72. Zeidler H., Kaltwasser J.P., Leonard J.P. et al. // J. Clin. Rheumatol. - 2002. - №8 (6). - P. 305-315.

МІСЦЕ МЕЛОКСИКАМУ В РЯДУ СУЧАСНИХ НЕСТЕРОЇДНИХ ПРОТИЗАПАЛЬНИХ ПРЕПАРАТІВ Г.В.Зайченко, О.М.Ляпунов, О.П.Безугла

Ключові слова: нестероїдні протизапальні препарати; мелоксикам; ревматологічні захворювання

Наведена фрармакологічна характеристика першого селективного інгібітора ЦОГ-2 мелоксикаму, відображені аспекти механізму його дії, вказані особливості фрармакодинаміки і показань до застосування, а також переваги препарату в порівнянні з класичними і високоселективними НПЗП за рівнем безпеки. Ефрективність та безпечність мелоксикаму підтверджені результатами 230 клінічних випробувань, в яких в цілому взяли участь більше 30 тис. пацієнтів. У більшості з них було доведено, що мелоксикам не поступається за ефективністю класичним НПЗП і при цьому володіє високим профрілем безпеки, перш за все щодо ШКТ. За вираженістю протизапальної та аналгетичної дії мелоксикам не поступається традиційним НПзП і вигідно відрізняється від них тим, що добре переноситься з урахуванням гастроінтестинальної і кардіоваскулярної безпеки, що дозволяє рекомендувати його як препарат першого вибору для лікування запальних і дегенеративних артропатій.

\section{МЕСТО МЕЛОКСИКАМА В РЯДУ СОВРЕМЕННЫХ НЕСТЕРОИДНЫХ ПРОТИВОВОСПАЛИТЕЛЬНЫХ ПРЕПАРАТОВ \\ А.В.Зайченко, А.Н.Ляпунов, Е.П.Безуглая}

Ключевые слова: нестероидные противовоспалительные препараты; мелоксикам; ревматологические заболевания

Приведена фрармакологическая характеристика первого селективного ингибитора ЦОГ-2 мелоксикама, отражены аспекты его механизма действия, указаны особенности фрармакодинамики и показаний к применению, а также преимущества препарата по сравнению с классическими и высокоселективными НПВП по уровню безопасности. Эфрфективность и безопасность мелоксикама подтверждены результатами 230 клинических испытаний, в которых в общей сложности приняли участие более 30 тыс. пациентов. В большинстве из них было доказано, что мелоксикам не уступает по эфффективности классическим НПВП и при этом обладает высоким профилем безопасности, прежде всего в отношении ЖКТ. По выраженности противовоспалительного и анальгетического эфрфектов мелоксикам не уступает традиционным НПВП и выгодно отличается от них хорошей переносимостью с учетом гастроинтестинальной и кардиоваскулярной безопасности, что позволяет рекомендовать его в качестве препарата первого выбора для лечения воспалительных и дегенеративных артропатий. 